4 ANALYTICAL SCIENCE

4 \& TECHNOLOGY

Vol. 26, No. 6, 357-363, 2013

Note

http://dx.doi.org/10.5806/AST.2013.26.6.357

\title{
Separation and identification of selenoproteins in selenium-enriched yeast
}

\author{
Kyong-Mi Kim and Yong-Nam Pak ${ }^{\star}$
}

Department of Chemistry Education, Korea National University of Education

Cheng-Won, Chung Buk 363-791, Korea

(Received August 26, 2013; Revised October 7, 2013; Accepted October 7, 2013)

\section{셀레늄이 강화된 이스트에서 셀레늄 단백질의 분리 및 확인 \\ 김경미 · 박용남` \\ 한국교원대학교 화학교육학과 \\ (2013. 8. 26. 접수, 2013. 10. 7. 수정, 2013. 10. 7. 승인)}

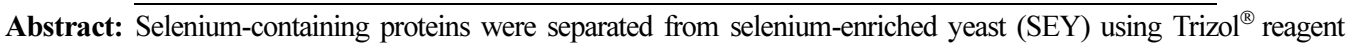
followed by anion exchange (AE) chromatography. This method is simpler and less time consuming than electrophoresis. Five selenium containing proteins were identified by on-line AE HPLC-ICP/MS (high performance liquid chromatography-inductively coupled plasma/mass spectrometry). Each protein was enzymatically hydrolyzed to seleno-amino acids and separated with RP (reverse phase) HPLC for the identification of selenoproteins.
\end{abstract}

Key words: Se-enriched yeast, HPLC-ICP/MS, selenoprotein, Trizol ${ }^{\circledR}$ reagent, anion exchange chromatography

\section{1. 서 론}

현대과학에서 가장 큰 관심의 분야는 생명에 관한 것이라고 볼 수 있는데 분석화학도 마찬가지로 생명 과학분야에 더 많은 관심을 갖게 되었다. 이러한 흐름 에서 최근에 나타나기 시작한 여러 -omics 분야가 있 으며 대표적으로 proteomics (단백체학)가 있다. 단백 체학이 단백질의 발현과 그 역할에 대한 연구를 하는 학문이라면 metallomics (금속체학)는 수년전부터 나타 난 분야로서 생체에 관련된 여러 금속과 단백질과의 상호작용 및 생체 내에서의 역할에 관한 연구 분야이 다. 예를 들어, 셀레늄은 여러 단백질 또는 효소(예;
글루타티온 과산화효소)와 함께 작용하여 인체에서 생명유지에 관한 중요한 역할들을 하는데, 이러한 셀 레늄을 포함한 분자와 단백질들을 분리하고 정량하며 또한, 생체에서의 대사와 그 역할을 연구하는 것은 매 우 중요하다. 셀레늄에 관한 중요도는 그 동안 여러 문헌들 ${ }^{1,2}$ 에 의하여 많이 언급되어 왔으며 여러 분야에 서 연구가 진행되고 있다. 셀레늄의 총량 분석부터 환 경 ${ }^{3,4}$ 과 식품 ${ }^{5-7}$ 의 셀레늄 함량, 혈장 ${ }^{8}$ 과 뇨 ${ }^{9}$ 등의 셀레늄 총량에서 점차로 인체 대사과정 화학종 구조 ${ }^{10,11}$ 및 seleno-amino acid ${ }^{12-14}$ 에서 셀레늄이 포함된 단백질 ${ }^{15-18}$ 로 점점 연구 분야를 넓혀가고 있다.

현재 여러 나라에서 셀레늄을 포함한 식품 및 의약

Corresponding author

Phone : +82-(0)43-230-3732 Fax : +82-(0)43-232-7176

E-mail : pakyn@knue.ac.kr 
품의 개발이 진행되고 있지만, 그 중 제일 보편화되 고 있는 것이 셀레늄이 강화된 이스트(seleniumenriched yeast; SEY)이다. SEY는 만들기가 간편하며, 제조과정에서 무기셀레늄을 생체에 섭취가 잘 되고 독성이 적은 유기셀레늄 형태로 전이시키기 때문에 동물의 사료나 의약품으로 가장 많이 쓰이고 있다. $\mathrm{SEY}$ 가 항암작용을 한다는 Clark 등의 보고 ${ }^{19}$ 에 따라 많은 연구가 진행되었고 셀레늄 총량의 분석부터 셀 레늄 화학종의 추출 및 셀레늄이 포함된 단백질의 구 조 연구까지 매우 다양하게 진행되고 있다. ${ }^{18,20} \mathrm{SEY}$ 에 대한 연구는 $\mathrm{SEY}$ 의 제조와 통제 뿐 아니라, SEY 내의 특성을 규명하여 차후의 연구에 중요한 바탕이 된다. 예를 들어, 셀레늄을 포함한 단백질이 어떠한 인체 대사과정 경로와 형태를 가지는지를 직접 확인 하기는 어렵지만 변인통제가 쉬운 동물에게 $\mathrm{SEY}$ 를 섭취하게 하여 동물의 대사과정을 살피는 연구가 가 능하다. 대사과정에서 어떠한 단백질로 변하는지 살 피기 위해서는 먼저 시료에 들어있는 셀레늄이 포함 된 단백질이 어떤 것인지 파악하는 것이 중요하다.

복잡한 이스트내의 셀레늄과 관련된 대사물질, 셀레 늄을 포함하는 작은 아미노산들, 그리고 셀레늄을 포 함하는 단백질들을 조사하고 정확히 분리 분석하는 것은 매우 어려운 기술이다. 복잡한 시료에서 화학종 들을 분리 및 검출하는 다양한 여러 기법들이 발전하 게 되었는데 현재, 대표적으로 HPLC-ICP/MS 또는 Gel-LA (laser ablation) ICP/MS 등이 있다. 이 기술들 은 장단점을 갖고 있으며 연구자들은 필요에 따라 여 러 다양한 기술들을 사용하고 있다.

현재 SEY에 포함된 단백질들을 분리하는데 가장 효과적인 기술은 전기영동법이라고 할 수 있다. 하지 만 이 기술은 시간이 많이 걸리는 단점이 있으며 분 리도가 높지 않아서 2차원 또는 다차원적인 전기영동 법을 적용하기도 한다. 또 다른 단점은 분리된 단백질 들을 검출하기가 어렵다는 것이다. 단백질이 분리된 부분을 물리적으로 떼어 내어 추출한 뒤에 분석하는 과정이 필요하며 이 과정에서는 손실이나 오염이 될 수 도 있다. 좀 더 최근에는 분리된 부분을 레이저 를 사용하여 이온화시켜 $\mathrm{ICP} / \mathrm{MS}$ 로 검출하거나 MALDI (matrix-assisted laser desorption ionization) 나 ESI (electrospray ionization)-TOF (time of flight)MS로 selenopeptide의 구조를 확인하는 연구법 ${ }^{15,21}$ 이 용이하게 잘 사용되고 있다. 하지만 이 기술에서는 현 대 분석화학에서 필수적인 정량적 분석이 어려운 단 점을 가지고 있다. 또 다른 방법은 크기배제 크로마토
그라피법 (SEC; size exclusion chromatography)을 사 용하여 일차적으로 단백질을 분리시키고 다시 음이온 교환 크로마토그라피법 또는 역상 크로마토그라피법 을 사용하는 연구들 ${ }^{20,22}$ 이 있다.

본 연구에서는 전기영동법이나 $\mathrm{SEC}$ 를 사용하지 않 고 이스트에서 단백질만을 분리 추출한 뒤, 이들을 음 이온 교환 크로마토그라피로 간단히 분리하고 이들 중에 셀레늄이 포함된 셀레노 단백질들을 찾아내었다. 즉, 단백질 분리시약인 $\mathrm{Trizol}^{\circledR}$ 로서 단백질과 RNA를 분리하고 분리된 단백질만을 음이온 교환컬럼을 통하 여 분리한 뒤 ICP/MS로 분석하는 것이다. 이 방법은 전기영동법을 사용하여 분리하는 것보다 시간적으로 빠르며 단백질만을 매트릭스에서 분리시키므로 깨끗 한 바탕을 얻을 수 있는 이점이 있다. 분리된 여러 셀 레노 단백질들은 다른 기술과 연계하여 더 깊은 연구 를 진행 할 수 있게 된다.

\section{2. 실 험}

팔중극자 반응셀(ORC; octopole reaction cell)이 장착 되어 있는 ICP MS 7500ce (Agilent Technology, Tokyo, Japan)에 HPLC (Wufeng, Shanghai, China)를 이용하고 음이온 교환 컬럼인 PRP-X100 SAX (Hamilton, MA, USA)를 사용하여 이스트에 함유된 셀레노 단백질을 분리하였다. 또한, 분리된 단백질은 단백질 분해효소 를 이용하여 가수분해시키고 $\mathrm{C}_{18}$ 역상 컬럼 (Discovery, Supelco, PA, USA)으로 seleno-amino acid를 분석하 였다.

\section{1. 시약 및 시료}

시약의 제조에 사용된 물 $\left(18.2 \mathrm{M} \Omega \mathrm{cm}^{-1}\right)$ 은 Milli-Q System (Millepore Co., USA)에서 제조된 탈이온수를 사용하였다. 모든 용기와 기구는 산세척 후 탈이온수 로 세척하여 사용하였다. 셀레늄 표준용액은 Sel-plex (2000 ppm, Alltech, USA)를 사용하였다. 별도로 기술 되지 않은 시약들은 가능한 최고 순도의 분석급 또는 이와 동일한 순도의 제품을 사용하였다.

셀레늄 화학종 표준용액은 Sigma-Aldrich (Saint Louis, MO, USA)에서 구입한 sodium selenite (Se IV, 99\%)와 sodium selenate (Se VI, 99.999\%), DL-SeMet (selenomethionine), L-SeCys (selenocyetein), MeSeCys (methylselenocystein)을 탈이온수에 묽혀 사용하였다. $\mathrm{SEY}$ 에서 단백질을 추출하기 위하여 사용한 $\mathrm{Trizol}^{\circledR}$ reagent, guanidine hydrochloride, sodium dodecyl sulfate 
(approx. 99\%), N,N,N',N'-tetramethylethylenediamine (99\%) 는 모두 Sigma-Aldrich에서 구입하여 사용하였고, 추 출된 단백질을 가수분해 하기 위해 protease XIV (bacterial, from streptomyces griseus)을 사용하였다.

$\mathrm{SEY}$ 의 단백질 분리에 사용된 이동상은 ammonium acetate $(95 \%)$ 를 탈이온수에 묽혀 사용하였다. 단백질 들을 가수분해시켜 얻은 아미노산을 역상 이온쌍 크 로마토그라피로 분리할 때는 $5 \%$ 메탄올 $(\mathrm{pH} 2.5)$ 을 사용하였고 이온쌍 시약은 $0.05 \%$ nonafluorovaleric acid (TCI, Tokyo, Japan)를 사용하였다.

\section{2. 기기 및 실험의 조건}

$\mathrm{ICP} / \mathrm{MS}$ 는 기기의 최적 상태에서 연구하기 위해서 실 험 전 $\mathrm{Y}$ 용액으로 최적조건을 구하고 $10 \mathrm{ppb}$ 셀레늄 표준 용액을 사용하여 셀레늄의 자연 동위원소 존재비 에 맞는지를 확인한 뒤 실험을 진행하였다. 기존의 시 료 운반기체에 $\mathrm{Ar} / \mathrm{O}_{2}$ 혼합 기체 $\left(\mathrm{Ar} 80 \%, \mathrm{O}_{2} 20 \%\right)$ 를 추 가로 사용하여 탄소를 산화시켰다. $\mathrm{Ar} / \mathrm{O}_{2}$ 의 양은 0.18 $\mathrm{L} / \mathrm{min}$ 로 설정하였다. ${ }^{23}$ 셀레노 단백질을 $\mathrm{ICP} / \mathrm{MS}$ 로 검 출할 때에 감도가 가장 높은 ${ }^{80} \mathrm{Se}$ 을 모니터링하였으며 $\mathrm{ORC}$ 에서의 충돌기체는 수소와 헬륨을 조사하였는데 수소가 더 좋은 결과를 보여주었으며 최적의 흐름속도 는 신호대 바탕값이 최대가 되는 $3.5 \mathrm{~mL} / \mathrm{min}$ 이었다.

단백질을 분리하기 위한 AE HPLC에서 컬럼은 강한 음이온 교환 컬럼인 Hamilton (Reno, NV, USA)의 PRP $\mathrm{X}-100(250 \mathrm{~mm} \times 4.1 \mathrm{~mm}, 10 \mu \mathrm{m})$ 을 사용하였고 이동 상의 흐름속도는 $1.5 \mathrm{~mL} / \mathrm{min}$ 으로 하였다. 이동상은 25 $\mathrm{mM}$ ammonium acetate (A)와 $250 \mathrm{mM}$ ammonium (B) 이며 완충용액으로 $\mathrm{pH} 5.5$ 에 맞추어 사용하였다. 셀레 노 단백질들은 다음의 기울기 용매법으로 추출되었는 데 그 조건은 다음과 같다. 초기의 $0 \sim 3 \mathrm{~min}$ 은 $\mathrm{A}$ 가 $100 \%$, 그리고 3 6 $\mathrm{min}$ 은 기울기로 B가 0-100\%, 그리 고 마지막 6 $20 \mathrm{~min}$ 은 $\mathrm{B}$ 를 $100 \%$ 로 하였을 때 가장 좋 은 분리도를 보여 주었다. 단백질을 가수분해시킨 뒤에 얻은 아미노산의 분리에서는 역상 이온쌍 크로마토그 라피를 사용하였는데 컬럼은 $\mathrm{C}_{18}$ 이었고 용리액은 $5 \%$ $\mathrm{MeOH}$, 이온쌍 시약은 $0.05 \%$ NFVA (nonafluorovaleric acid)를 사용하였다. 용리액의 흐름 속도는 $1.0 \mathrm{~mL} / \mathrm{min}$ 이었으며 이 들의 최적조건을 Table 1에 나타내었다.

\section{3. 단백질 추출 실험 과정}

2.3.1. 초음파추출을 이용한 단백질 분리

이 방법은 비록 추출효율이 $10 \%$ 내외이지만 비교
Table 1. Optimized conditions for IC-PMS and HPLC

\begin{tabular}{|c|c|}
\hline \multicolumn{2}{|l|}{ ICP-MS } \\
\hline rf power & $1500 \mathrm{~W}$ \\
\hline Carrier gas & $0.95 \mathrm{~L} / \mathrm{min}$ \\
\hline $\mathrm{Ar} / \mathrm{O}_{2}$ auxiliary gas & $0.18 \mathrm{~L} / \mathrm{min}$ \\
\hline Collision gas & $\mathrm{H}_{2}, 3.5 \mathrm{~mL} / \mathrm{min}$ \\
\hline \multicolumn{2}{|l|}{ HPLC } \\
\hline AE column & $\begin{array}{l}\text { PRP X-100 SAX column } \\
(250 \mathrm{~mm} \times 4.1 \mathrm{~mm}, 10 \mu \mathrm{m})\end{array}$ \\
\hline Injection volume & $100 \mu \mathrm{L}$ \\
\hline Flow rate & $1.5 \mathrm{~mL} / \mathrm{min}$ \\
\hline Mobile phase & $\begin{array}{l}\text { Buffer A: } \\
25 \mathrm{mM} \text { ammonium acetate, } \mathrm{pH} 5.5 \\
\text { Buffer B(gradient): } \\
250 \mathrm{mM} \text { ammonium acetate, } \mathrm{pH} 5.5 \\
0 \sim 3 \mathrm{~min} \text { : A } 100 \% \\
3 \sim 6 \mathrm{~min} \text { : up to } \mathbf{B} 100 \% \\
6 \sim 20 \mathrm{~min} \text { : B } 100 \%\end{array}$ \\
\hline Column & Discovery $\mathrm{C}_{18}$ column \\
\hline Injection volume & $100 \mu \mathrm{L}$ \\
\hline Flow rate & $1.0 \mathrm{~mL} / \mathrm{min}$ \\
\hline Mobile phase & $5 \%$ methanol $(\mathrm{pH} 2.5)$ \\
\hline Ion-paring reagent & $0.05 \%$ nonafluorovaleric acid (NFVA) \\
\hline
\end{tabular}

적 간단하므로 $\mathrm{Trizol}^{\circledR}{ }^{\circledR}$ 방법과 비교하기 위하여 사용하 였다. 보관할 때에는 아르곤 기체 조건하에서 $-20{ }^{\circ} \mathrm{C}$ 에 서 보관하였다.

2.3.2. Trizol $^{\circledR}$ reagent extraction을 이용한 단백질 분리 Trizol $^{\circledR}$ 시약을 이용하여 SEY 시료에서 단백질만 분리한 뒤 $\mathrm{AE}$ 컬럼으로 단백질들을 분리하였다. 시 료 $80 \mathrm{mg}$ 에 $\mathrm{Trizol}^{\circledR}$ 시약 $1.0 \mathrm{~mL}$ 를 넣은 다음 0.2 $\mathrm{mL}$ 의 chloroform을 가하여 15 초간 흔들어 주었다. 실온에서 약 2-3 분간 둔 다음 $12,000 \mathrm{~g}$ 로 원심분리 시키고 유기층을 분리시켰다. 약 $1.5 \mathrm{~mL}$ 의 isopropanol 을 넣고 10 분간 상온에 둔 다음에 $12,000 \mathrm{~g}$ 로 다시 원심분리시키고 상등액을 제거하여 남은 단백질을 분리하였다. 단백질을 씻기 위하여 침전된 단백질을 $2 \mathrm{~mL}$ 의 $0.3 \mathrm{M}$ guanidine in $95 \% \mathrm{EtOH}$ 용액으로 씻고 20 분간 상온에 둔 다음, $4{ }^{\circ} \mathrm{C}$ 에서 15 분간 $7,500 \mathrm{~g}$ 로 원심분리시킨 후 용액을 제거한다. 이 과 정을 2 회 반복후에 마지막으로 단백질에 $2 \mathrm{~mL}$ 의 $\mathrm{EtOH}$ 을 넣고 상온에 20 분간 둔 뒤에 원심분리 $(7,500 \mathrm{~g})$ 를 $4{ }^{\circ} \mathrm{C}$ 에서 15 분간 하고 에탄올을 제거 하였다. 


\section{3. 결과 및 고찰}

\subsection{Se-containing protein 분리}

$\mathrm{SEY}$ 에서 단백질을 추출하는 방법은 여러 가지가 있지만 초음파를 이용한 추출이 간단하며 시간이 짧 게 걸린다. 하지만 이스트에 흡착된 여러 셀레늄과 대 사물질들 그리고 수용성 단백질만 추출이 되며, 그 효 율이 높지 않기 때문에 일반적으로 사용할 수는 없지 만 정성적인 정보는 제공할 수 있을 것이다. 우선 일 차적으로 초음파를 사용한 추출물에 대하여 $\mathrm{AE}$ $\mathrm{HPLC}-\mathrm{ICP} / \mathrm{MS}$ 를 적용하고 그 결과를 나타내었다(Fig. 1). 단백질은 25 분경에 한 개의 피크만 나타났으며 앞부분에서 일찍 나오는 피크들은 분자량이 작은 셀 렌을 포함한 셀레늄 아미노산이나 대사물질로 추정된 다. ${ }^{21}$ 이를 뒷받침하기 위하여 초음파로 추출된 시료 를 $\mathrm{Trizol}^{\circledR}$ 시약으로 단백질만을 분리하고 AE HPLC$\mathrm{ICP} / \mathrm{MS}$ 를 적용하여 본 결과, 동일한 23 분대에서만 피크가 나타났다. 따라서 머무름 시간이 7 분 이전의 피크들은 단백질이 아님을 알 수 있다. 결국, Trizol ${ }^{\circledR}$

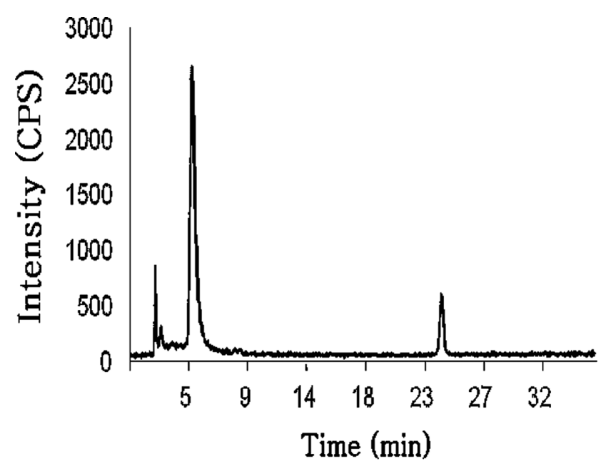

(a)
시약을 이용한 단백질의 추출은 시료 이스트에서 다 른 찌꺼기와 RNA 등을 모두 제거하고 단백질만을 분 리하여 채취하는 것이기 때문에 분리에 효율적임을 보여주고 있다.

$\operatorname{Trizol}^{\circledR}$ 만을 사용하여 $\mathrm{SEY}$ 에서 직접 단백질을 추출 한 경우에는 5 개의 피크로 다르게 나타났으며(Fig. 2) 초음파를 사용한 경우보다 더 나은 결과를 보여주 고 있다. 초기의 연구에서는 앞의 4 개의 단백질은 잘 분리가 되었으나 5 번째의 피크는 피크들이 겹쳐서 나 오는 것으로 보였다. 분리조건을 향상시켰을 때에 5 번 째와 6번째 피크를 분리시킬 수 있었는데 마지막 6 번 째 피크는 단백질이 아닌 $[\mathrm{BrH}]^{+}$에 의한 간섭으로 보 인다. 즉, $\mathrm{Br}$ 이 용리되면서 충돌셀에서 충돌기체인 수 소와 $[\mathrm{BrH}]^{+}$를 생성하고 이 때문에 $m / z$ 80에서 피크 를 보여주고 있다. 실제로 이 6번째 피크를 가수분해 시켰을 때에 셀레노 아미노산이 검출되지 않았다.

$\mathrm{SEY}$ 의 단백질의 분리연구에서 $\mathrm{SEC}$ 를 사용하여 단 백질을 분리하는 것이 일반적인 첫 번째 단계이지만 $\mathrm{SEC}$ 의 분리능이 크지 않으므로 단백질들을 모두 분

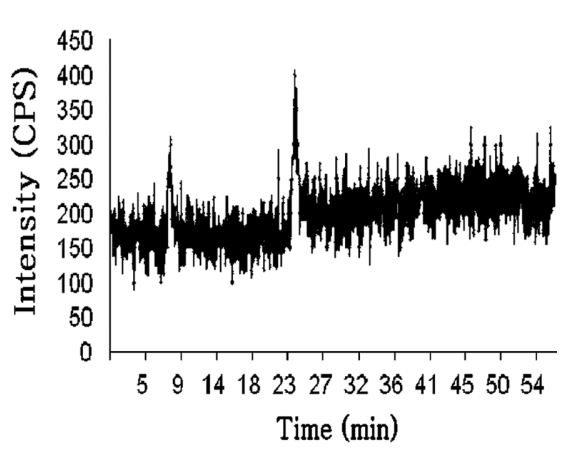

(b)

Fig. 1. Comparison of ultrasonic bath extraction (a) and Trizol ${ }^{\circledR}$ extraction (b) for SEY selenoproteins with AE HPLC-ICP/MS.

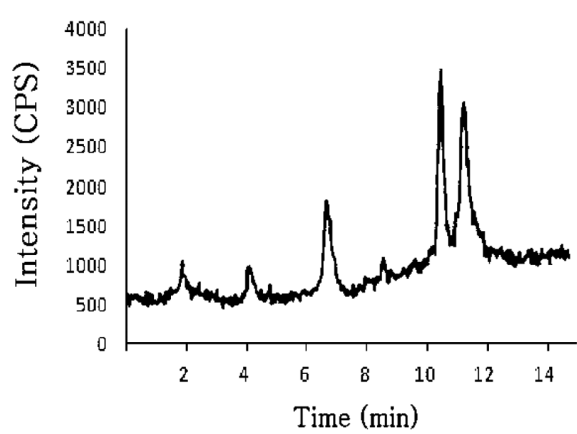

(a)

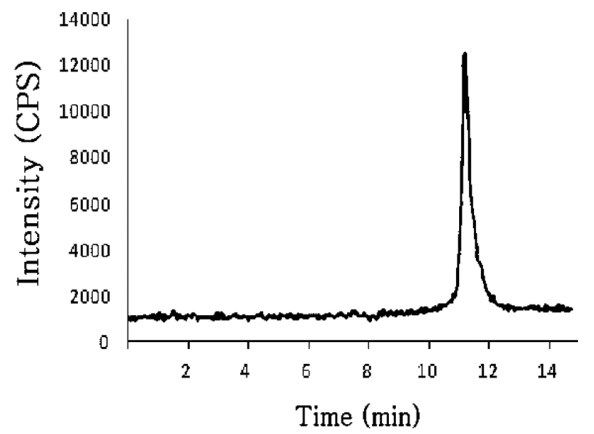

(b)

Fig. 2. Identification of 5 selenium containing proteins in SEY with AE HPLC-ICP/MS after Trizol ${ }^{\circledR}$ extraction. $m / z \quad 80$ is monitored for (a) and $m / z 79$ for $\mathrm{Br}$ is monitored for (b). 


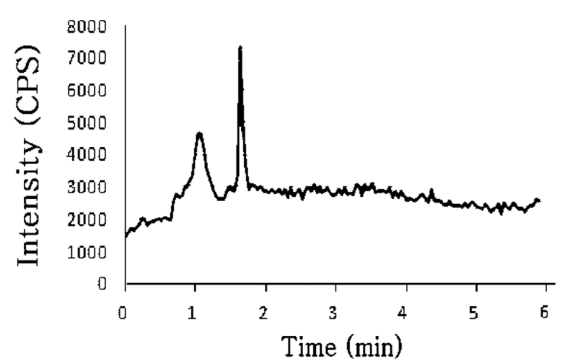

(a)

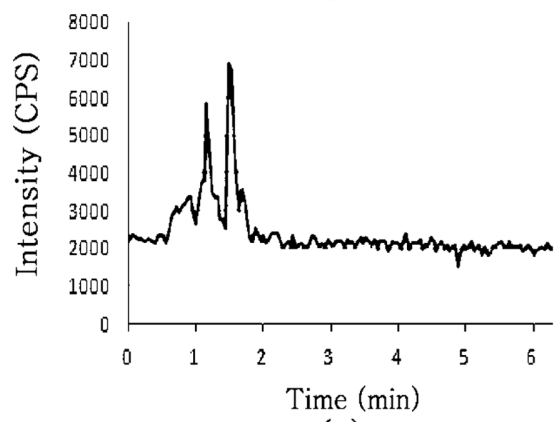

(c)

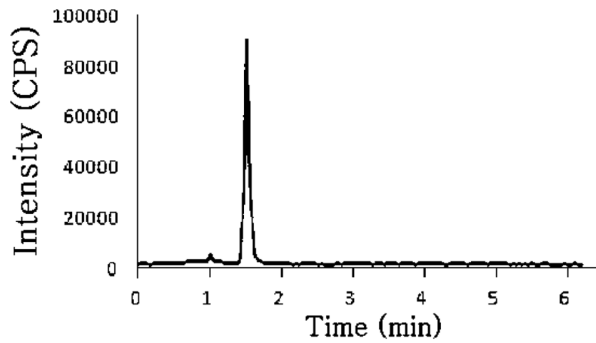

(b)

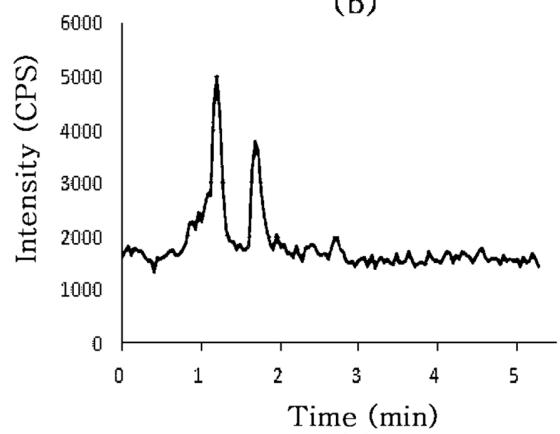

(d)

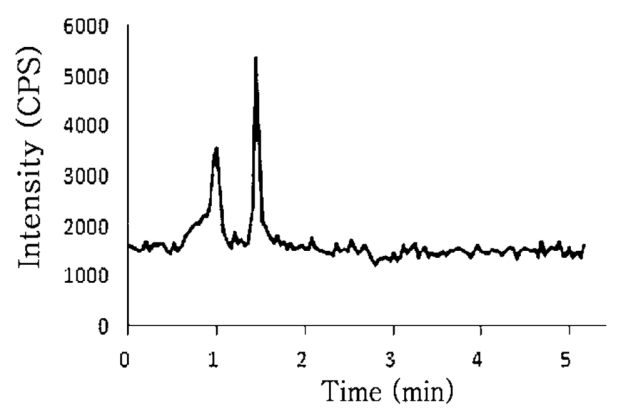

(e)

Fig. 3. RP HPLC-ICP/MS chromatograms after enzymatic hydrolysis of selenium containing proteins for (a) 1st fraction, (b) 2nd fraction, (c) 3rd fraction, (d) 4th fraction, and (e) 5th fraction of AE HPLC. All fractions have SeCys (1.2 min) and SeMet $(1.7 \mathrm{~min})$ except $(\mathrm{b})$. There was a time lag of $0.2 \mathrm{~min}$ in case of (e) ${ }^{80} \mathrm{Se}$ is monitored.

리하는 것은 쉬운 일이 아니며 분리에 시간이 많이 걸린다. 단백질들은 크기에 따라 분리가 되지만 분리 능이 크지 않다. 따라서 분리능을 높이기 위하여 2D 크로마토그라피등이 이용된다. Mcsheehy ${ }^{22}$ 는 SEY 시 료를 trypsin으로 분해시켜 추출한 단백질과 펩티드들 을 SEC를 이용하여 분리시키고 nano HPLC ESI-MS/ $\mathrm{MS}$ 로 구조를 확인하였다. 하지만 trypsin의 사용으로 단백질들이 일부 가수분해될 수 있다. 조금 더 효율적 으로 단백질을 분리하기 위하여 전기영동을 사용하기 도 한다.

또 다른 단백질의 분리는 전기영동법이다. $\operatorname{Tastet}^{21}$ 는 셀레늄이 강화된 이스트에서 초음파를 사용하여
단백질을 추출해 내고(효율 $17 \%$ 이내) $2 \mathrm{D}$ 전기영동 으로 단백질들을 분리시켰을 때에 $20.1 \mathrm{kDa}$ 근처에 3 개 그리고 $14.4 \mathrm{kDa}$ 근처에서 2 개의 spot들을 얻었다. 이 때 5 개의 단백질을 얻었다고 보고하였는데 본 연 구에서 얻은 결과와 일치한다. 본 연구에서 사용한 Trizol $^{\circledR}$ 을 이용한 단백질 분리 및 AE HPLC 방법은 Tastet의 방법보다 빠르고 더 쉬우며 무엇보다 셀레노 단백질의 확인이 용이하다. 즉, 전기영동에서 얻은 spot들은 직접적으로 셀레노 단백질인지 확인할 수 없 으며 이들을 다시 추출하여 $\mathrm{ESI} \mathrm{MS} / \mathrm{MS}$ 로 확인하였 지만, 본 연구에서는 $\mathrm{AE} \mathrm{HPLC}$ 의 용리액에서 직접 $\mathrm{ICP} / \mathrm{MS}$ 로 연결하여 쉽게 셀레노 단백질을 확인할 수 
있다는 이점이 있다.

\subsection{Seleno-amino acids 분리 및 확인}

추출된 단백질을 $\mathrm{AE} \mathrm{HPLC}$ 를 이용하여 5 개의 피 크로 분리하였다. 분리된 셀레늄 단백질들을 효소를 이용하여 가수분해시켜 셀레노 아미노산으로 만든 뒤 $\mathrm{C}_{18} \mathrm{RP}$ HPLC-ICP/MS를 이용하여 분리시켜 검출하고 그 결과를 Fig. 3에 나타내었다. 용리된 피크 1-5번은 모두 셀레노 아미노산을 포함하고 있었고 따라서 5 개의 피크는 모두 셀레노 단백질임을 다시 확인하였 다. 아미노산들은 주로 SeCys과 SeMet이었으며 단백 질들은 서로 다른 아미노산 형태를 보여 주었다. 무기 셀레늄은 생체나 음식내에서는 잘 발견되지 않으며 셀레늄은 주로 유기셀레늄으로 생체내에서 작용하는 데 본 연구의 결과도 다른 문헌과 같은 결과를 보여 주고 있다. ${ }^{24} \mathrm{SeCys}$ 는 유전자의 명령에 의하여 합성이 되며 SeMet은 셀레늄이 황의 자리에 임의로 치환되어 생길 수 있기 때문에 모든 단백질에서 SeMet이 검출 되었다. 특히 2nd fraction은 다른 단백질과는 다르게 주로 SeMet 만으로 이루어져 있다. 즉, 이 단백질은 엄밀한 의미의 셀레노 단백질(selenoprotein)이 아닌 셀레늄을 포함한 단백질(selenium-containing protein) 이라는 것을 알 수 있었다.

\section{4. 결 론}

본 연구에서는 Se-enriched yeast에서 효과적으로 단 백질을 추출하기 위하여 Trizol ${ }^{\circledR}$ reagent를 사용하였다. 전처리 과정에서 단백질만을 남기고 다른 물질들은 모두 제거하여 분광학적 방해를 최소화하였다. 추출된 단백질을 AE HPLC-ICP/MS를 사용하여 5 개의 셀레 노 단백질로 분리하고 검출하였다. 또한 각 단백질을 가수분해시키고 RP HPLC-ICP/MS로 분리 검출하여 각 단백질은 셀레늄을 포함한 단백질임을 재확인하였 고 단백질에 대한 정보를 더 얻을 수 있었다. 특히, 2nd fraction은 다른 단백질과는 다르게 SeMet 만으로 이루어져 있음을 알 수 있었다.

단백질만을 추출하여 분리할 때에 기존의 전기영동 법에 비하여 시간이 더 절약되고 간편하다. SEC 방법 과 비교할 때에 분리능이 증가하여 단백질 분리에 더 효과적이며 매트릭스 분리가 잘 되었다. 본 연구를 통 해 이스트에서의 셀레노 단백질에 대한 정보를 잘 얻 어낼 수 있었다. 다만 각 단백질의 구조를 확인하기 위하여서는 ESI-MS와 같은 또 다른 질량 분석법을
사용해야 할 것이다.

\section{감사의 글}

본 연구는 한국연구재단의 일반연구(2010-0010880) 의 도움으로 이루어진 것으로 이에 감사드립니다.

\section{참고문헌}

1. C. Reilly, 'Selenium in Food and Health', 2nd ed., Springer, London, 2006.

2. U. Tinggi, Toxicol. Lett., 137, 103-109 (2003).

3. V. Ermakov, L. Jovanovic, J. of Geochem. Explor., 107, 200-205 (2010)

4. H. Qin, J. Zhu and H. Su, Chemosphere, 86, 626-633 (2012).

5. M. Bajaj, E. Eiche, T. Neumann, J. Winter and C. Gallert, J. Hazard. Mater, 189, 640-646 (2011).

6. M. Panigati, L. Falciola, P. Mussini, G. Beretta and R. M. Facino, Food Chemistry, 105, 1090-1098 (2007).

7. M. Germ, V. Stibilj, S. Kreft, A. Gaberšk, F. Pajk and I. Kref, Food Chemistry, 117, 204-206 (2009).

8. C. Lin, L. Wang and K. Shen, J. Clin. Lab. Anal., 23, 192-195 (2009)

9. G .P. Walker, F. R. Dunshea, J. W. Heard and C. R. Stockdale, J. of Dairy Sci., 93, 10, 4644-4650 (2010).

10. K. T. Suzuki, Y. Tsuji, Y. Ohta and N. Suzuki, Toxicol. and Appl. Pharm., 227, 76-83 (2008).

11. Y. Lu, A. Rumler, K. A. Francesconi and S. A. Pergantis, Anal. Chim. Acta, 731, 49-59 (2012).

12. C. Thiry, A. Ruttens, L. D. Temmerman, Y. Schneider and Luc Pussemier, Food Chemistry, 130, 767-784 (2012).

13. K. Pyrzynska, Food Chemistry, 114, 1183-1191 (2009).

14. O. Prince, O. Amoako, P. C. Uden and J. F. Tyson, Anal. Chim. Acta, 652, 315-323 (2009).

15. G. Ballihaut, C. Pe'cheyran, S. Mounicou, H. Preudhomme, R. Grimaud, and R. Lobinski, Trends in Anal. Chem., 26, 183-190 (2007).

16. Z. Pedrero, J. R. Encinar, Y. Madrid and C. Cámara, J. Chromatogr. A, 1139, 247-253 (2007).

17. C. F. Harrington, R. Clough, L. Rovinski, S. J. Hill and J. F. Tyson, J. Anal. At. Spectrom., 26, 1561-1567 (2011). 
18. G. Ballihaut, L. X. Kilpatrick, E. L. Kilpatrick and W. Davis, J. Anal. At. Spectrom., 26, 383-394 (2011).

19. L. C. Clark, G. F. Combs, B. W. Turnbull, E. H. Slate, D. K. Chalker, J. Chow, L. S. Davis, R. A. Glover, G. F. Graham, E. G. Gross, A. Krongrad, J. L. Lesher, H. K. Park, B. B. Sanders, C. L. Smith and J. R. Taylor, J. Am. Med. Assoc., 276, 1957-1963 (1996).

20. S. McSheehy, W. Yang, F. Pannier, J. Szpunar, R. Lobinski, J. Auger and M. Potin-Gautier, Anal. Chim.
Acta, 421, 147-153 (2000).

21. L. Tastet, D. Schaumloffel, B. Bouyssiere and R. Lobinski, Talanta, 75, 1140-1145 (2008).

22. S. McSheehy, F. Pannier, J. Szpunar, M. Potin-Gautier and R. Lobinski, Analyst, 127, 223-229 (2002).

23. H. Cho and Y. Pak, J. Kor. Chem. Soc., 55, $472-477$ (2011).

24. A. Ruttens, L. D. Temmerman, Y. Schneider and L. Pussemier, Food Chemistry, 130, 767-784 (2012). 